\title{
ANALISIS KESALAHAN SISWA DALAM MENYELESAIKAN SOAL CERITA PERBANDINGAN BERDASARKAN PROSEDUR NEWMAN PADA SISWA KELAS VII SMP NEGERI 14 BALIKPAPAN TAHUN AJARAN 2018/2019
}

\author{
Noor Laila ${ }^{1}$, Husnul Khotimah ${ }^{2}$, Besse Intan Permatasari ${ }^{3}$ \\ Universitas Balikpapan ${ }^{1}$, Universitas Balikpapan ${ }^{2}$, Universitas Balikpapan ${ }^{3}$ \\ pos-el: noorlaila288@gmail.com ${ }^{1}$, husnul.khotimah@uniba-bpn.ac.id ${ }^{2}$, \\ besse.intan@uniba-bpn.ac.id ${ }^{3}$
}

\begin{abstract}
ABSTRAK
Penelitian ini bertujuan untuk mengetahui besar persentase dan mendeskripsikan penyebab dari kesalahan yang dilakukan siswa dalam menyelesaikan soal cerita matematika materi perbandingan senilai dan berbalik nilai berdasarkan prosedur Newman. Jenis penelitian ini adalah penelitian deskriptif. Subyek penelitian ini adalah siswa kelas VII SMP Negeri 14 Balikpapan. Teknik analisis data menggunakan tiga tahap yaitu reduksi data, penyajian data, dan penarikan kesimpulan serta menggunakan tabel bantuan untuk mengetahui besar persentase kesalahan siswa. Siswa diberikan tes dalam bentuk soal cerita materi perbandingan senilai dan berbalik nilai serta dilakukan wawancara. Hasil pekerjaan subyek dianalisis berdasarkan prosedur Newman. Dalam penelitian ini diperoleh hampir seluruh kesalahan dilakukan oleh siswa meliputi kesalahan memahami sebesar 43,2\% yang disebabkan karena kurang memahami dengan apa yang diminta dalam soal, kesalahan transformasi sebesar $75,7 \%$ yang disebabkan karena kurang memahami rumus yang harus digunakan, kesalahan keterampilan proses sebesar 78,6\% yang terjadi karena kurang teliti dalam melakukan proses perhitungan, dan kesalahan penulisan jawaban sebesar 49,3\% yang disebabkan karena terburu buru dalam proses mengerjakan dan tidak terbiasa menuliskan kesimpulan.
\end{abstract}

Kata Kunci : Soal Cerita, Prosedur Newman, Perbandingan Senilai dan Berbalik Nilai

\begin{abstract}
This study aims to determine the large percentage and describe the causes of errors made by students in solving mathematical story problems comparative material worth and turn around values based on the Newman procedure. This type of research is descriptive research. The subjects of this study were grade VII students of SMP Negeri 14 Balikpapan. The data analysis technique uses three stages, namely data reduction, data presentation, and drawing conclusions and using a help table to find out the percentage of student errors. Students were given a test in the form of a comparative story matter question and turned value and were interviewed. The results of the subject's work were analyzed based on Newman's procedure. In this study, almost all errors made by students included understanding errors of 43,2\% caused by lack of understanding of what was asked in the problem, transformation errors of 75,7\% caused by lack of understanding of the formula to be used, errors of process skills of 78,6\% that occurs due to inaccuracy in the calculation process, and writing errors in the answers of 49,3\% caused by being rushed in the process of working and not accustomed to writing conclusions.
\end{abstract}

Keywords: Story Problem, Newman Procedure, Comparison of Value and Turning Values 


\section{PENDAhuluan}

Matematika merupakan salah satu mata pelajaran yang memiliki peranan penting dalam dunia pendidikan. Matematika dalam pelaksanaan pendidikan diajarkan di setiap institusiinstitusi pendidikan, baik di tingkat SD, SMP, SMA, hingga perguruan tinggi. Selain itu, matematika juga memiliki peranan penting dalam kehidupan manusia karena berpengaruh pada perkembangan semua bidang ekonomi, teknologi, sosial, dan sebagainya. Hal ini didukung oleh pendapat Susilo (Trapsilo, Kriswandani, \& Prihatnani, 2016, p. 1) bahwa matematika merupakan ilmu yang mendasari dan memiliki peran penting bagi perkembangan ilmu-ilmu pengetahuan yang lainnya.

Gunawan (Trapsilo, Kriswandani, \& Prihatnani, 2016, p. 2) juga mengemukakan bahwa matematika merupakan salah satu dari dua mata pelajaran yang mempunyai peluang besar untuk siswa dalam membuat kesalahan. Selain itu, siswa kurang perhatian terhadap pelajaran matematika. Hal ini dikarenakan siswa menganggap matematika merupakan pelajaran yang susah dipahami sehingga siswa tidak ingin mengulang kembali pelajaran yang telah diberikan oleh guru (Susilo, 2018). Istiqomah \& Zakiyah (2017, p. 3) menjelaskan kesalahan dalam menyelesaikan soal dapat diartikan sebagai penyimpangan dari jawaban yang benar yang dilakukan oleh siswa, hal ini dapat terjadi karena beberapa hal diantaranya yaitu kurangnya kompetensi siswa dalam menguasai materi atau tidak menjawab dan menyelesaikan soal. Pada Peraturan Menteri Pendidikan Nasional (Melanie, Hartoyo, \& Ahmad, 2016, p. 1), dikemukakan dengan tegas bahwa siswa dituntut untuk memiliki keterampilan pemecahan masalah (problem solving) dalam menyelesaikan masalah matematika. Dalam menyelesaikannya, siswa diharapkan dapat memahami masalah yang disajikan dan mengetahui maksud soal. Setelah siswa memahami masalah, mereka diminta untuk dapat merancang model matematika sesuai dengan pemahaman masalah yang dapat membantu memberi arahan dalam menyelesaikan model serta menafsirkan jawaban numeriknya pada masalah yang disajikan.

Masalah dalam matematika biasanya disajikan dalam bentuk soal cerita, penggambaran fenomena atau peristiwa, ilustrasi gambar atau teka-teki (Trapsilo, Kriswandani, \& Prihatnani, 2016, p. 2). Salah satu bentuk soal yang sering muncul dalam matematika yaitu soal cerita. Penyebab kesalahan yang dilakukan siswa menurut Malau (Trapsilo, Kriswandani, \& Prihatnani, 2016, p. 2) antara lain karena kurangnya pemahaman atas materi yang dipelajari, kurangnya penguasaan bahasa matematika, kurang tepat dalam menerapkan rumus, proses perhitungan yang salah, kurang teliti, dan kesalahan dalam memahami konsep. Salah satu materi matematika yang sering muncul dalam bentuk soal cerita adalah materi perbandingan senilai dan berbalik nilai. Penyelesaian soal-soal cerita yang berkaitan dengan perbandingan senilai dan berbalik nilai merupakan salah satu 
materi yang membuat siswa kesulitan dalam proses penyelesaiannya, dimana siswa harus terlebih dahulu memahami makna dalam soal cerita, membedakan antara permasalahan perbandingan senilai atau perbandingan berbalik nilai, kemudian mengubahnya ke dalam bentuk model matematika.

Hal ini juga dialami oleh sebagian dari para siswa di kelas VII SMP Negeri 14 Balikpapan. Pendidik yang mengajar dikelas tersebut mengungkapkan bahwa terdapat beberapa siswa yang melakukan kesalahan dalam menyelesaikan soal cerita matematika salah satunya pada materi perbandingan senilai dan berbalik nilai. Oleh karena itu untuk mengetahui alasan yang menyebabkan siswa melakukan kesalahan dalam memahami soal perbandingan senilai dan berbalik nilai pada bentuk soal cerita maka perlu dilakukan analisis kesalahan siswa dalam pengerjaan soal. Terdapat teori-teori tentang analisis kesalahan, salah satu yang dapat digunakan untuk menganalisis kesalahan soal cerita adalah dengan menggunakan Teori Newman.

Newman adalah seorang guru bidang studi matematika di Australia yang pertama kali memperkenalkan analisis kesalahan pada tahun 1977. Menurut Newman (Trapsilo, Kriswandani, \& Prihatnani, 2016, p. 4) kesalahan dalam mengerjakan soal matematika dibedakan menjadi lima tipe kesalahan, yaitu reading error (kesalahan membaca), comprehension error (kesalahan memahami), transformation error (kesalahan dalam transformasi), process skills error (kesalahan dalam keterampilan proses), dan encoding error (kesalahan dalam penarikan kesimpulan). Teori analisis Newman telah digunakan oleh beberapa peneliti untuk menganalisis kesalahan penyelesaian soal cerita matematika. Jamal (2018) menggunakan prosedur Newman untuk menganalisis kesalahan dalam menyelesaikan pertidaksamaan kuadrat, sedangkan Widodo, Sujadi, \& Mardiyana (2017) menggunakan prosedur Newman untuk menganalisis kesalahan dalam menyelesaikan soal kesebangunan. Oleh karena itu, teori Newman dipandang cocok untuk menganalisis kesalahan siswa dalam menyelesaikan masalah perbandingan senilai dan berbalik nilai yang memuat soal cerita.

Berdasarkan permasalahan yang telah dipaparkan, peneliti tertarik untuk melakukan Analisis Kesalahan Siswa dalam Menyelesaikan Soal Cerita Matematika Perbandingan Berdasarkan Prosedur Kesalahan Newman.

\section{METODE PENELITIAN}

Penelitian ini menggunakan pendekatan kualitatif. Menurut Moleong (2017, p. 4), penelitian kualitatif merupakan penelitian yang menghasilkan data deskripsi berupa katakata tertulis, gambar, dan bukan angka, dimana data-data tersebut didapatkan dari orang-orang dan perilaku yang diamati. Jenis penelitian yang digunakan dalam penelitian ini adalah penelitian deskriptif. Arikunto (2013, p. 3) menjelaskan penelitian deskriptif adalah penelitian yang benar-benar hanya memaparkan apa yang terdapat atau 
terjadi dalam suatu wilayah tertentu, tujuan utama penelitian deskriptif adalah untuk menggambarkan secara sistematis fakta dan karakteristik objek atau subyek yang diteliti secara tepat. Pemilihan subyek dilakukan dengan teknik purposive sampling. Sugiono (Komariyah, Afifah, \& Resbiantoro, 2018) menyatakan bahwa purposive sampling adalah teknik pengumpulan sampel dengan pertimbangan tertentu. Dalam penelitian ini pemilihan kelas sebagai sampel dilakukan berdasarkan pertimbangan guru mata pelajaran matematika kelas VII SMP Negeri 14 Balikpapan yaitu kelas VII C yang berjumlah 35 siswa. Menurut Gay dan Diehl (Toha, Mirza, \& Ahmad, 2015, p. 5) untuk metode deskriptif pengambilan sampel minimumnya adalah $10 \%$ dari jumlah siswa. Dari hal tersebut dalam penelitian ini diambil sebanyak 6 orang siswa secara acak untuk dilakukan wawancara berdasarkan pertimbangan peneliti yang mewakili kategori tinggi, sedang, dan rendah sesuai dengan yang dikemukakan Setiawan (Trapsilo, Kriswandani, \& Prihatnani, 2016, p. 6).

Dalam penelitian ini, teknik pengumpulan data yang digunakan antara lain dokumentasi yaitu berupa foto-foto hasil pekerjaan siswa, dan dokumentasi pelaksanaan penelitian, tes berbentuk soal cerita yang memuat materi tentang perbandingan senilai dan berbalik nilai sebanyak 8 soal, dan wawancara yang dilakukan dengan siswa dari subyek yang telah ditentukan dengan maksud untuk mengetahui dan menangkap secara langsung seluruh informasi tentang penyebab kesalahan siswa dalam menyelesaikan soal cerita perbandingan senilai dan berbalik nilai. Wawancara yang digunakan berupa wawancara tidak terstruktur, yaitu wawancara yang bebas dimana peneliti tidak menggunakan pedoman wawancara yang telah tersusun untuk pengumpulan datanya. Pedoman wawancara yang digunakan hanya berupa garis-garis besar permasalahan yang akan ditanyakan.

Teknik analisis data dalam penelitian ini meliputi analisis hasil tes siswa mengenai soal cerita materi perbandingan senilai dan berbalik nilai berdasarkan prosedur Newman untuk mengetahui besar persentase kesalahan yang dilakukan oleh siswa dengan menggunakan tabel bantuan. Setelah itu dilakukan wawancara dengan subyek yang telah ditentukan untuk mengetahui penyebab-penyebab kesalahan yang dilakukan oleh siswa berdasarkan prosedur Newman.

\section{HASIL DAN PEMBAHASAN}

Kesalahan adalah kekeliruan yang diperbuat oleh seseorang dalam menyelesaikan tugas yang telah diberikan (Yulia, Fauzi, \& Awaluddin, 2017, p. 127). Kesalahan merupakan pendeskripsian jenis-jenis kesalahan yang dilakukan oleh siswa dan alasan tentang penyebab terjadinya kesalahan yang bertujuan untuk mengetahui keadaan yang sebenarnya. Dalam menyelesaikan suatu permasalahan, siswa seringkali mengalami hambatan, sehingga banyak melakukan kesalahan dalam menjawab permasalahan tersebut. Dalam penelitian ini, akan dianalisis 
kesalahan-kesalahan yang paling banyak terjadi oleh siswa ketika menjawab suatu permasalahan.

Penelitian ini dilakukan dengan memberikan tes materi perbandingan senilai dan berbalik nilai yang berjumlah 8 soal uraian kepada siswa. Soal tes materi perbandingan senilai dan berbalik nilai dibuat berdasarkan kisi-kisi, kemudian divalidasikan kepada validator ahli dan telah diuji kevalidannya dan reliabilitasnya. Setelah itu, tes dilaksanakan dan diikuti oleh siswa kelas VII C SMP Negeri 14 Balikpapan dengan jumlah 35 siswa. Berikut disajikan hasil keseluruhan kesalahan berdasarkan prosedur Newman yang dilakukan siswa:

Tabel 1

Persentase Kesalahan Berdasarkan Prosedur Newman

\begin{tabular}{|c|l|c|c|c|c|}
\hline \multirow{2}{*}{$\begin{array}{c}\mathrm{N} \\
\mathrm{o}\end{array}$} & \multirow{2}{*}{$\begin{array}{l}\text { Ketera- } \\
\text { ngan }\end{array}$} & \multicolumn{4}{|c|}{$\begin{array}{c}\text { Jenis Kesalahan } \\
\text { Berdasarkan Prosedur }\end{array}$} \\
\cline { 2 - 6 } Newman \\
\hline 1 & $\begin{array}{l}\text { Jumlah } \\
\text { Siswa }\end{array}$ & 35 & 35 & 35 & 35 \\
\hline \multirow{2}{*}{2} & $\begin{array}{l}\text { Total } \\
\text { Seluruh } \\
\text { Kesalah } \\
\text { an dari } \\
\text { Tiap } \\
\text { Aspek }\end{array}$ & 280 & 280 & 280 & 280 \\
\hline \multirow{2}{*}{3} & $\begin{array}{l}\text { Total } \\
\text { Kesalah } \\
\text { an yang } \\
\text { Terjadi }\end{array}$ & 121 & 212 & 219 & 138 \\
\hline 6 & $\begin{array}{l}\text { Persen- } \\
\text { tase }\end{array}$ & $\begin{array}{c}43,2 \\
\%\end{array}$ & $\begin{array}{c}75,7 \\
\%\end{array}$ & $\begin{array}{c}78,2 \\
\%\end{array}$ & $\begin{array}{c}49,3 \\
\%\end{array}$ \\
\hline
\end{tabular}

Keterangan:

KM : Kesalahan Memahami

KT : Kesalahan Transformasi

KP : Kesalahan Keterampilan Proses

KJ : Kesalahan Penulisan Jawaban
Berdasarkan Tabel 1, dapat dilihat bahwa persentase paling besar dari kesalahan yang terjadi setelah dilakukan tes yaitu pada kesalahan Keterampilan Proses sebesar 78,2\%, kemudian Kesalahan Transformasi sebesar 75,7\%, Kesalahan Penulisan Jawaban sebesar 49,3\%, terakhir Kesalahan Memahami sebesar $43,2 \%$.

Setelah hasil tes siswa dianalisis untuk diketahui kesalahan-kesalahan yang dilakukan, kemudian dilakukan wawancara dengan 6 siswa sebagai subyek untuk mengetahui penyebab kesalahan yang dilakukan siswa berdasarkan prosedur Newman. Berdasarkan hasil wawancara penelitian untuk mengetahui penyebab dari kesalahan yang dilakukan oleh siswa yang diwakili dengan subyek yang telah ditentukan, untuk kesalahan membaca yang dapat dilihat dari hasil wawancara diperoleh bahwa tidak ada siswa yang melakukan kesalahan membaca karena bentuk soal cerita yang mudah dipahami,

Untuk kesalahan memahami, merupakan kesalahan yang paling rendah yang terjadi dari siswa. Siswa cenderung tidak menyebutkan secara lengkap informasi yang terdapat pada soal hal ini dikarenakan informasi yang diketahui sudah ada pada soal sehigga dirasa tidak perlu untuk ditulis kembali, hanya menuliskan salah satunya saja yang disebabkan karena kurang teliti dalam memahami apa yang diminta dalam soal, dan terburu-buru saat mengerjakan soal.

Penyebab kesalahan ini juga diungkapkan oleh Islamiyah, Prayitno, \& Amrullah (2018, hal. 71) yang menjelaskan bahwa penyebab siswa tidak 
menuliskan diketahui dan ditanyakan pada umumnya siswa tidak terbiasa dan malas untuk menuliskannya karena untuk mempersingkat waktu dan hal tersebut sudah ada pada soal jadi tidak perlu untuk dituliskan lagi, tidak teliti, bingung, dan tidak terbiasa menuliskan informasi yang diketahui dan ditanyakan pada soal. Kesalahan ini dapat diminimalisir dengan cara membiasakan siswa menyelesaikan soal-soal cerita sehingga akan mengasah keterampilan siswa dalam memahami masalah yang ada pada soal secara keseluruhan sehingga dapat merencanakan penyelesaian dengan tepat.

Selanjutnya untuk kesalahan transformasi, pada kesalahan ini siswa cenderung menuliskan rencana penyelesaian yang kurang tepat, kesalahan ini terjadi dikarenakan sebagian besar siswa kurang memiliki pemahaman tentang materi yang diberikan, tidak teliti dalam memahami apa yang diminta dalam soal, terburuburu dalam mengerjakan soal, lupa dengan rumus-rumus yang seharusnya digunakan untuk penyelesaian soal.

Kesalahan transformasi juga terjadi karena siswa jarang menghadapi soal, siswa tidak dapat merencanakan solusi untuk mengerjakan soal, siswa lupa tentang materi dan rumus yang harus digunakan, kurang latihan mengerjakan soal-soal bentuk cerita dengan variasi yang berbeda, dan salah dalam menentukan operasi matematika yang digunakan (Yusnia \& Fitriyani, 2017). Untuk meminimalisir kesalahan transformasi yang dilakukan siswa dalam menyelesaikan soal cerita yaitu dengan menekankan kembali cara dan rumus- rumus hitung materi yang diajarkan sehingga siswa dapat mengubah bentuk matematika dengan benar (Widhiyassifah \& Sumardi, 2018, hal. 5)

Kesalahan keterampilan proses yang dilakukan siswa antara lain yaitu menyelesaikan soal dengan prosedur yang tidak jelas yang disebabkan karena tidak mengetahui dan memahami cara penyelesaian yang benar, langkahlangkah yang digunakan untuk membuat penyelesaian juga belum tepat, selain itu siswa juga melakukan kesalahan proses pada saat proses perhitungan, hal ini disebabkan karena siswa kurang teliti dan terburu-buru ketika mengerjakan soal.

Sughesti, Muhsetyo, \& Susanto (2017, p. 567) menjelaskan kembali bahwa kesalahan keterampilan proses terjadi ketika siswa tidak mengetahui prosedur atau langkah-langkah yang akan digunakan untuk menyelesaikan soal dengan tepat. Untuk meminimalisisr kesalahan ini, hal yang dapat dilakukan yaitu menekankan pada siswa tentang langkah-langkah penyelesaian soal sesuai dengan materi yang diajarkan, dan memperhatikan pengetahuan dasar saat mengajarkan materi baru sehingga siswa dapat memahami konsep (Widhiyassifah \& Sumardi, 2018, hal. 6).

Terakhir adalah kesalahan pada penulisan jawaban, yang meliputi siswa tidak menuliskan kesimpulan dari soal yang disebabkan karena tidak terbiasa untuk menuliskan kesimpulan di akhir penyelesaian, dan disebabkan juga karena lupa untuk menuliskan kesimpulan ketika mengerjakan soal, selain itu juga siswa melakukan kesalahan karena menuliskan kesimpulan yang salah, hal ini disebabkan 
karena pada proses penyelesaian yaitu penggunaan rumus dan proses perhitungan yang dilakukan salah, maka akan membuat kesimpulan akhir juga salah.

Islamiyah, Prayitno, \& Amrullah (2018, hal. 73) mengungkapkan kesalahan penulisan jawaban dilakukan karena siswa belum terbiasa menuliskan kesimpulan dari soal yang penting mereka sudah mendapatkan jawabannya. Untuk meminimalisir kesalahan penulisan jawaban yang dilakukan oleh siswa dapat dilakukan dengan cara siswa dibiasakan untuk menyelesaikan soal cerita secara lengkap dan dibiasakan juga untuk mengecek pekerjaannya kembali sebelum dikumpulkan.

\section{KESIMPULAN}

Berdasarkan hasil penelitian dan pembahasan, dapat disimpulkan beberapa hal sebagai berikut: 1) Besar persentase jenis kesalahan yang dilakukan siswa berdasarkan prosedur Newman meliputi: (a) Kesalahan Memahami, kesalahan ini merupakan kesalahan yang paling rendah terjadi yaitu sebesar $43,2 \%$, (b) Kesalahan Transformasi, kesalahan ini merupakan kesalahan tertinggi kedua yang terjadi yaitu sebesar 75,7\%, (c) Kesalahan Keterampilan Proses, merupakan kesalahan yang paling tinggi terjadi yaitu sebesar 78,6\%, (d) Kesalahan Penulisan Jawaban, kesalahan ini terjadi sebesar $49,3 \%$. 2) Penyebab terjadinya kesalahan yang dilakukan siswa berdasarkan prosedur Newman: (a) Penyebab Kesalahan Memahami antara lain merasa tidak perlu menuliskan kembali karena sudah ada pada soal, kurang teliti dalam memahami apa yang diketahui dan ditanyakan dalam soal, serta terburu-buru dalam mengerjakan soal. (b) Penyebab Kesalahan Transformasi antara lain tidak memahami materi, kurang teliti dalam mengerjakan, terburu-buru, dan lupa dengan rumus yang harus digunakan. (c) Penyebab Kesalahan Keterampilan Proses antara lain belum tepat dalam menentukan langkah-langkah penyelesaian, tidak teliti dan terburu-buru saat melakukan proses perhitungan. (d) Penyebab Kesalahan Penulisan Jawaban antara lain tidak terbiasa dan lupa untuk menuliskan kesimpulan.

\section{DAFTAR PUSTAKA}

Arikunto, S. (2013). Prosedur Penelitian : Suatu Pendekatan Praktik. Jakarta: Rineka Cipta.

Islamiyah, A. C., Prayitno, S., \& Amrullah. (2018, April). Analisis Kesalahan Siswa SMP pada Penyelesaian Masalah Sistem Persamaan Linear Dua Variabel. Jurnal DIdaktik Matematika, 5(1), 66-76.

Istiqomah, I., \& Zakiyah, N. (2017). Analisis Kesalahan Siswa Dalam Menyelesaikan Soal Cerita Pada Materi Pecahan Kelas IV SD. Universitas Muhammadiyah Sidoarjo, 1-11.

Jamal，F. (2018，September). Analisis Kesalahan dalam Menyelesaikan Soal Cerita Pertidaksamaan Kuadrat Berdasarkan Prosedur Newman. Maju, 5(2), 41-51.

Komariyah, S., Afifah, D. S., \& Resbiantoro, G. (2018). Analisis Pemahaman Konsep Dalam Memecahkan Masalah Matematika Ditinjau Dari Minat 
Belajar SOSIOHUMANIORA, 4, 1-8.

Melanie, M. E., Hartoyo, A., \& Ahmad, D. (2016). Deskripsi Penyelesaian Soal Cerita Materi Perbandingan PAda Siswa Kelas VII SMP. Program Studi Pendidikan Matematika FKIP Untan, 1-11.

Moleong, L. J. (2017). Metodologi Penelitian Kualitatif Edisi Revisi. Bandung: $\quad$ PT. Remaja Rosdakarya.

Sughesti, M. M., Muhsetyo, G., \& Susanto, H. (2017). Jenis Kesalahan Siswa Dalam Menyelesaikan Soal Cerita Berdasarkan Prosedur Newman. Pendidikan Matematika Pascasarjana Universitas Negeri Malang, 563-572.

Susilo, G. (2018). Analisis Kesulitan Siswa Sekolah Menengah Atas Kota Balikpapan Dalam Memecahkan Masalah Yang BErkaitan Dengan Persamaan Kuadrat Dan Fungsi Kuadrat Tahun Ajaran 2014/2015. de Fermat: Jurnal Pendidikan Matematika, 1(2), 61-71.

Toha, M., Mirza, A., \& Ahmad, D. (2015). Analisis Kesalahan Siswa dalam Menyelesaikan Soal Cerita Materi Perbandingan di Kelas VII SMP. Program Studi Pendidikan Matematika FKIP UNTAN, 1-10.

Trapsilo, T. E., Kriswandani, \& Prihatnani, E. (2016). Analisis Kesalahan Menurut Teori Newman dalam Menyelesaikan
Soal Cerita Materi Persamaan Linear Dua Variabel pada Siswa Kelas IX SMP N 1 Banyubiru. Jurnal, 1-19.

Widhiyassifah, R., \& Sumardi. (2018). Analisis Kesalahan dalam Menyelesaikan Soal Eksponen pada SIswa Kelas X di SMA Negeri 1 Kartasura. Prosiding, 18.

Widodo, A. N., Sujadi, I., \& Mardiyana. (2017). Analisis Kesalahan Siswa dalam Menyelesaikan Soal Kesebangunan Berdasarkan Prosedur Newman Ditinjau dari Kemampuan Spasial (Penelitian dilaksanakan di Kelas IX SMPN 1 Paguyangan Kabupaten Brebes). Journal of Mathematics and Mathematics Education, 7(1), 1320.

Yulia, R., Fauzi, \& Awaluddin. (2017, Februari). Analisis Kesalahan Siswa Mengerjakan Soal Matematika di Kelas V SDN 37 Banda Aceh. Jurnal Ilmiah Pendidikan Guru Sekolah Dasar, 2(1), 124-131.

Yusnia, D., \& Fitriyani, H. (2017). Identifikasi Kesalahan Siswa Menggunakan Newman's Error Analysis (NEA) pada Pemecahan Masalah Operasi Hitung Bentuk Aljabar. Seminar Nasional Pendidikan, Sains dan Teknologi Fakultas Matematika dan Ilmu Pengetahuan Alam Universitas Muhammadiyah Semarang, 78-83. 